\title{
Hedge Fund Regulation and Systemic RISK
}

\author{
Robert J Bianchi and Michael E Drew*
}

\begin{abstract}
The global financial crisis (GFC) caused catastrophic losses in the highly regulated banking sector. In contrast, the largely unregulated global hedge fund industry navigated through the crisis relatively unscathed. As a consequence of the GFC, there is a tidal wave of opinion calling for reform of the global financial architecture, with a specific emphasis on tightened oversight of hedge funds. In this article, we consider the debate regarding the future of hedge fund regulation, building the case that regulatory reform to constrain excessive leverage must be applied in equal measure to all financial market participants, not just hedge funds. The challenge for regulators is to carefully craft a regime of transparency and disclosure that minimises the potential for systemic risk without jeopardising the financial innovation and entrepreneurship that are emblematic of the hedge fund sector.
\end{abstract}

\section{Introduction}

As a consequence of the global financial crisis (GFC), greater regulatory oversight of the global hedge fund industry is being touted as one of the reforms to improve the stability of global financial markets. ${ }^{1}$ The enormous growth in the global hedge fund industry has seen their funds under management (FUM) increase from US\$38 billion in 1990 to US\$1.3 trillion as at the end of 2008. ${ }^{2}$ The high growth rates of FUM and the demise of the long-term capital management (LTCM) hedge fund in 1998 have seen the reputation of the hedge fund industry shift from that of investment darlings to predatory villains. The events of the LTCM crisis highlighted systemic weaknesses in the global financial system, such as the limits of risk management systems, excessive leverage and counter-party risks. ${ }^{3}$

Since the demise of LTCM, many have argued that the next financial crisis would originate from the lowly or virtually unregulated hedge fund industry. ${ }^{4}$ One of the ironies of the current GFC is that its epicentre occurred

Robert J Bianchi is a Senior Lecturer in the Department of Accounting, Finance and Economics, Griffith Business School, Griffith University. Michael E Drew is Professor of Finance, Griffith Business School, Griffith University.

Aguilar (2009); IOSC (2009b); Bookstaber (2009).

Aguilar (2009).

Refer to Edwards (1999), The President's Working Group on Financial Markets (1999);

Lowenstein (2001).

Sants (2008). 
in the most highly regulated sectors of financial markets, the global banking system. ${ }^{5}$ The events of the GFC has brought into question the role and effectiveness of current banking and financial market regulation. Despite the unfolding events of the GFC in the highly regulated banking sector, the calls for further regulation on all finance participants is well underway. ${ }^{6}$

The aim of this article is to review the hedge fund industry and the current regulatory framework that surrounds it. We assess the proposed recommendations for hedge fund regulation and look at whether they will be effective in achieving their desired objectives. We explore two key reforms to reduce the likelihood of systemic risk in global financial markets and the hedge fund industry. First, we propose the introduction of regulation to constrain excessive leverage. The over-extension of credit has been determined as a primary contributor of the GFC and many other crises in the annals of financial history. ${ }^{7}$ The financial and tax systems in many countries strongly incentivise individuals and corporations to over-leverage through the tax-deductibility of debt-financed investments. Furthermore, banks are inherently highly leveraged institutions through the fractional reserve banking mechanism.

We compare bank leverage versus hedge fund leverage and find that the gearing levels of the hedge fund industry are of little concern in comparison to commercial and investment banks around the world. To reduce the likelihood of systemic risk in the future, we posit that regulatory reform to moderate excess leverage is more urgently required in the banking sector rather than narrowly targeted controls on the global hedge fund industry.

Second, the lack of regulatory oversight in the global hedge fund industry means that little empirical information is available on transactional activity, market positions and risk statistics. As a result, the opaque nature of the hedge fund industry makes it difficult for academics, regulators and industry professionals to propose genuine financial market reform. All hedge fund regulations and reforms to date have been based on circumstantial information rather than supported by empirical evidence. We call for the introduction of higher disclosure levels of individual hedge fund positions to regulators in order to close this information gap. It is argued that individual hedge fund positions remain anonymous or 'unidentified' so that valuable or private information remains in the hands of hedge funds that have acquired a competitive advantage. These disclosures by individual funds can then be aggregated to provide a better understanding of the hedge fund industry and whether it genuinely poses a systemic risk. A carefully designed disclosure framework is required before the hedge fund regulation debate can move forward.

Refer to de Larosiere (2009) and FSA (2009). Furthermore, the Basel II Capital Accord was recently introduced as the global banking standard for risk management. Clearly, this most recent global regulatory framework for the banking sector can now be considered flawed in the wake of the post-GFC era.

Aguilar (2009), RBA (2009).

de Larosiere (2009); Ferguson (2008); FSA (2009). 


\section{Overview of Hedge Funds}

The first known hedge fund was established by Australian-born Alfred Winslow Jones as a US general partnership in 1949. ${ }^{8}$ The term 'hedge fund' originates from a Forbes magazine article and was coined to describe Jones' unique investment strategy at the time. ${ }^{9}$ Alfred Jones managed an investment portfolio that held long stock positions in companies that he believed were under-valued and constructed short stock positions in companies that were regarded as too expensive. The combination of long and short positions in stocks shifted the risk of the portfolio from market timing to security selection.

Today, the term 'hedge funds' is a catch-all phrase used to describe a heterogeneous group of non-traditional fund managers. While academics, industry professionals, regulators and the media tend to extensively use the 'hedge fund' term, the reality is that hedge funds are notoriously difficult to define in a clear and cogent manner. ${ }^{10}$ Hedge funds tend to own holdings and exposures in a wide range of asset markets and investment strategies, making them difficult to clearly define within a concise set of definitive terms. The following definitions provide a sense of the challenges faced by regulatory agencies in their attempt to define the hedge fund industry:

Although it is not statutorily defined, the term (hedge fund) encompasses any pooled investment vehicle that is privately organised, administered by professional investment managers, and not widely available to the public. (President's Working Group on Financial Markets, 1999, p 1)

Although there is no universally accepted definition of the term 'hedge fund', the term is generally used to refer to an entity that holds a pool of securities and perhaps other assets, whose interests are not sold in a registered public offering and which is not registered as an investment company under the Investment Company Act. (US Securities Exchange, 2003, p viii)

Although the term is widely used, there is no clear definition of what constitutes a hedge fund. For the purposes of this article, hedge funds are regarded as funds that have some of the following characteristics, (i) funds that rely heavily on a single strategy, with broad delegations for the use of gearing and derivatives, (ii) funds that have a reliance

$8 \quad$ Chua and Woodward (1983) document John Maynard Keynes as the First Bursar of the Chest Fund at King's College, Cambridge from 1927 to 1945. This fund managed by Keynes held positions in common stocks, currencies and commodity futures. In today's parlance, the Chest Fund would be classified as a 'global macro' hedge fund. The performance of the Chest Fund documented in Chua and Woodward (1983) suggests that Keynes was an exceptional investment manager.

9 Loomis (1966).

10 IOSCO (2009b) states that, 'The IOSCO Technical Committee acknowledges in its Consultation Report that there is no consistent or agreed-upon definition of the term hedge fund'. (p 4) 
upon a single individual to execute the investment management process, (iii) a relatively short trading history; and/or (iv) target an absolute return rather than a benchmark return. (APRA, 2003)

These definitions from selected government agencies reflect the heterogeneous nature of the global hedge fund industry. Hedge funds, by their very nature, are designed to provide maximum flexibility in their investment philosophy, style and return generation process. The work of de Brouwer suggests that hedge funds are defined by what they are not, rather than what they are. ${ }^{11}$ To better appreciate the activities of hedge funds, the following two sections define hedge funds by: (1) their methods of investment; and (2) their regulatory environments in Australia and the United States.

\section{Hedge Fund Investment Methods}

One of the unique features of the hedge fund industry is the assortment of investment strategies and styles available to investors. ${ }^{12}$ Many financial market participants do not describe hedge funds by the legal structures; rather, they are defined by the nature of their investment strategies. ${ }^{13}$ Philipp Cottier defines hedge funds as collective legal investment schemes that offer non-traditional investment funds and programs in areas such as emerging markets, high yield, leveraged buyouts (LBOs), private equity, venture capital (VC), distressed securities, asset- and mortgage-backed securities, convertibles and commodity markets. ${ }^{14}$ This definition articulates the scope of hedge fund investment participation in global asset markets. Nonetheless, the three key hedge fund characteristics that differentiate them from other market participants are their ability to construct both long and short positions in markets, their use of leverage, and the fact that they employ derivatives for both hedging and speculative purposes. These alternative investment techniques provide some sectors of the hedge fund industry with the tools to earn returns that are different to traditional asset classes.

As a consequence of these alternative investment techniques, researchers have examined the differences in hedge fund investment styles. For instance, hedge fund database vendors such as Hedge Fund Research (HFR) classify hedge funds into 29 different investment categories, while others such as Reuters/Lipper/TASS classify hedge funds into 11 primary

de Brouwer (2001).

Fung and Hsieh (1999).

Aguilar (2009).

14 In contrast, Cottier (1997) defined a traditional investment fund or program as those who develop long positions in assets such as liquid shares in developed markets, cash, fixed interest, real estate and other traditional-type investment funds. Traditional funds do not engage in short sales exposures, leverage is minimal and derivatives are used for hedging purposes only. Other researchers, such as Lhabitant (2004), employ a broader hedge fund definition by describing them as 'privately organized, loosely regulated and professionally managed pools of capital not widely available to the public' ( $\mathrm{p} 4)$. 
hedge fund investment categories. ${ }^{15}$ Academic studies have examined the number of hedge fund investment styles and have revealed mixed results, with estimates of up to eight different investment styles. These academic findings are different from the views proposed by industry professionals. ${ }^{16}$

\section{Current Hedge Fund Regulatory Environment}

Hedge funds operate under different regulatory environments in Australia and the United States. This section of the article reviews these two jurisdictions to demonstrate the level of flexibility that hedge fund managers seek for themselves and their investors. This review of the regulatory environments gives us an appreciation of why hedge funds are legally and operationally distinct from other market participants in the United States; however, they are as effectively regulated as other entities within the Australian regime. We commence with the Australian regulatory framework and then proceed to the more cumbersome US legal environment.

\section{Australian Legal Framework}

All hedge funds operating any form of financial services business in Australia require licensing under the Corporations Act 2001 from the Australian Securities and Investments Commission (ASIC). Regardless of the country of origin or domicile, all hedge funds operating any form of business in Australia are required to operate under an Australia Financial Services License ('AFSL') pursuant to section 913B of the Corporations Act 2001. The AFSL provides the licensee with the authority to carry on a financial services business to: (1) provide financial product advice; (2) deal in financial products; and/or (3) provide custodial or depository services to wholesale or retail clients, or both.

As part of the AFSL, each licensee must agree to abide by a Schedule of Conditions that is determined by ASIC; these conditions either relate to various components of the Corporations Act 2001 or are specifically related to the individual financial services business. They include key person requirements, compliance measures, financial requirements under the licence, reporting requirements under the licence, audit requirements and other matters. The licensee must establish and maintain measures to ensure that the entity and its representatives comply with the obligations under the Corporations Act 2001. To operationalise this, the licensee must keep records about how these measures are implemented and monitored. ASIC monitors AFS licensees by performing random audits on AFSLs and by

Refer to www.hedgefundresearch.com for the list of 29 HFR investment categories. The Thomson/Reuters/Lipper/TASS organisation (www.hedgeworld.com) classifies the global hedge fund industry into the 11 investment styles of: Long/Short Equity, Convertible Arbitrage, Event Driven, Global Macro, Fund of Funds, Fixed Income Arbitrage, Emerging Markets, Equity Market Neutral, Managed Futures, Dedicated Short Bias and Multi-Strategy (Other).

16 See Brown and Goetzmann (2003); Fung and Hsieh (1997). 
conducting investigatory audits from formal licensee complaints from the general public.

The issue with the current AFSL licensing regime is that the legislation inadequately addresses the problem of systemic risk. While an AFSL licence-holder must report their minimum solvency requirements to ASIC, the effectiveness of this disclosure to regulators is cumbersome compared with the speed of catastrophic financial events. Furthermore, it is difficult for a hedge fund or many other AFSL licence-holders to know whether they themselves pose a systemic risk to the Australian finance industry, as few would know their proportional contribution of market exposures in the overall Australian financial system. The lack of hedge fund disclosure and its impact on systemic risk are being addressed through regulatory reform, and form part of the analysis in subsequent sections of this article.

\section{US Legal Framework}

The US legal environment for hedge funds is designed to provide exclusions from regulation and disclosure. As a result, the US hedge fund industry operates with maximum flexibility to both hedge funds and their investors. Hedge funds are typically structured as a limited partnership, as a limited liability corporation, or as an offshore corporation. The work of de Brouwer informs us that US hedge funds are generally structured to elude five significant US federal laws: the Securities Act 1933, the Securities Exchange Act 1934, the Investment Company Act 1940, the Investment Advisers Act 1940 and the Commodity Exchange Act 1974.

First, the Securities Act 1933 requires entities that issue securities to be registered with the US Securities and Exchange Commission (SEC) and to provide extensive disclosure through their prospectuses. Hedge funds circumvent this requirement via section 4(2) and regulation D of the Act, exempting funds that offer securities by private placement, which are securities that are not offered via public advertisement or appeal.

Second, the Securities Exchange Act 1934 provides regulatory oversight to brokers and dealers and requires them to become members of a registered national securities exchange or association. Under this Act, entities are required to keep detailed information on their financial dealing and customer transactions. Hedge funds avoid the Securities Exchange Act 1934, as they are considered traders who trade on their own account rather than brokers or dealers who transact on behalf of other entities.

Third, the Investment Company Act 1940 is legislation designed to increase investor protection by requiring independent boards with at least 60 per cent external board members, with restrictions on leverage and derivatives. Hedge funds circumvent this legislation via two exemptions in the Act. Under Section 3(c)(1) of the Act, a fund can qualify for exemption if the number of investors is restricted to 100 (ie one general partner and 99 limited partners) and the fund is not offered to the public. The second exemption under this Act increases the number of investors to 499 provided that each investor is 'qualified' as individuals with assets of at least $\$ 5$ million or entities with at least $\$ 25$ million in investments. The 
Investment Company Act 1940 also imposes the 'fulcrum' rule on mutual funds, whereby performance fees must exhibit symmetric gains or losses relative to a benchmark. The exemption of the Investment Company Act 1940 allows hedge funds to receive asymmetric fees from their clients. ${ }^{17}$

Fourth, the Investment Advisers Act 1940 requires investment advisers to be registered with the SEC when they receive compensation for advice. ${ }^{18}$ Performance-based compensation is restricted under this Act unless Rule 205-3 is exercised, where exemptions exist for clients with at least US $\$ 500,000$ under management and a net worth in excess of US\$1 million. Furthermore, a fund is exempt from SEC registration as an investment adviser under section 203(b)(3) provided that the investment adviser does not solicit business and has fewer than 15 clients during the past 12 months. US hedge funds circumvent this legislation by exercising the above exemptions.

Fifth, the Commodity Exchange Act 1974 is designed for exchanges to monitor exchange traded derivative positions to ensure that no single entity is large enough to pose potential systemic risk to US futures exchanges. This is a law that is difficult for hedge funds to avoid unless they are a non-US domiciled fund and trade with a non-US futures account.

It is clear that US hedge funds are legally structured to avoid specific legislation in order to achieve maximum flexibility for themselves and their investors. It is also clear that the minute details of the US regulatory environment provide enough exemptions for US hedge funds to circumvent many established regulations that govern US financial markets. Similar to the Australian regulatory regime, the US legal environment is silent regarding the management of systemic risk and its effects from excessive leverage and the lack of disclosure.

Overall, the key difference between these legislative frameworks is that all hedge funds are regulated via the AFSL in Australia while the same fund operating in the United States can avoid almost all US regulation. The similarity between both regulatory environments is their silence on the employment of leverage and their ability to adequately address systemic risk. Unlike the heavily regulated banking sector in both countries, the amount of leverage employed in the hedge fund industry is determined by market discipline. To reduce the likelihood of systemic risk, we address the issues of excessive leverage and the lack of disclosure in the forthcoming sections on current regulatory reform and their implications.

Refer to Fung and Hsieh (1999) for more details on the fulcrum rule.

18 On 2 December 2004, the SEC adopted a new rule amendment under the Investment Advisers Act 1940. The new amendment required hedge funds to register as investment advisers by 1 February 2006 via the filing of the Form ADV with the SEC. On 23 June 2006, the US Court of Appeals for the District of Columbia Circuit vacated the rule changes, and hedge funds are now no longer required to register as investment advisers. See Brown et al (2008) for more details. 


\section{The Role of Hedge Funds}

Over the past decade, many have examined the role of hedge funds in global financial markets. ${ }^{19}$ With the benefit of hindsight in a post-GFC world, the International Organization of Securities Commissions (IOSCO) has declared that the primary role of hedge funds is to act as intermediation services in financial markets and that they should be compensated for taking on these risks. ${ }^{20}$ Hedge funds facilitate the provision of liquidity, price efficiency, risk distribution and financial integration, and deliver diversification benefits. To provide these intermediation services, hedge fund investors must bear risk that provides them with a market rate of return. The role of hedge funds in markets can be summarised in the following way.

\section{Provision of Liquidity}

Hedge funds provide a valuable contribution to market liquidity. Kathleen Casey of IOSCO and Ben Bernanke of the US Federal Reserve both agree on the growing importance of hedge funds as liquidity providers in various markets. ${ }^{21}$ Traditionally, the intermediation service of liquidity provision has been the exclusive domain of financial institutions. In recent years, these financial institutions have shifted their revenue streams towards agent fees rather than operating through risk-taking activities. More specifically, the global banking sector has reduced its risk-taking activities with the migration towards the Basel II Accord. ${ }^{22}$ These risk-taking activities of liquidity provision have been absorbed by the global hedge fund industry. ${ }^{23}$ The introduction of hedge fund regulation in the future must be crafted carefully to ensure that overall market liquidity does not suffer, especially given the current problems associated with liquidity in the post-GFC period. ${ }^{24}$ Future regulation that restricts hedge fund market activities may cause hedge funds

19 Refer to Agarwal and Naik (2004); Edwards and Gaon (2003); Fung and Hsieh (1997).

20 Kathleen Casey, Chairperson of the IOSCO Technical Committee, said: 'Securities regulators recognise that the current crisis in financial markets is not a hedge fund driven event. Hedge funds contribute to market liquidity, price efficiency, risk distribution and global market integration. Nevertheless the crisis has given regulators the opportunity to consider the systemic role hedge funds may play and the way in which we deal with the regulatory risks they may pose to the oversight of markets and protection of investors.' IOSCO (2009a).

${ }^{21}$ See Kathleen Casey quote in IOSCO (2009a). Also refer to Bernanke (2007), who states: ' $[\mathrm{M}]$ ost economists agree that the rise of hedge funds has been a positive development for investors and for financial markets. They have stimulated an extraordinary amount of financial innovation in recent years, and, using many of these new financial tools, they have greatly enhanced the liquidity, efficiency, and risk-sharing capabilities of our financial system.'

22 Herring (2004).

23 Agarwal et al (2009); Mitchell and Pulvino (2001); Scholes (2004).

24 To provide debt financing certainty, the national governments of many developed economies (including Australia) have provided guarantees to investors who purchase bank debt instruments for limited time periods. 
to not enter distressed markets at any price (due to regulatory constraints). As a result, it may exacerbate financial crises in the future due to the withdrawal of liquidity caused by the lack of potential buyers. ${ }^{25}$

\section{Price Efficiency}

Hedge funds aid in fostering market efficiency and stability as price-takers and/or market-makers. ${ }^{26}$ Studies have demonstrated the various techniques hedge funds employ as arbitrageurs in asset markets. ${ }^{27}$ Government agencies have recognised that hedge fund activities improve market pricing and efficiency. ${ }^{28}$

\section{Risk Distribution}

Hedge funds contribute to the function of transferring and distributing risk in financial markets. In the pre-hedge fund era, many risks were borne by the commercial and investment banking sector due to their willingness to fund and hold these transactions directly on their balance sheets. With the introduction of the Basel I Accord (the global banking standard) in 1992 and the recent migration towards Basel II since 2004, banks began to shift these risks off their balance sheets via securitisation and on-sold them to other financial market participants, including hedge funds. The growth of the hedge fund industry has seen the emergence of entities with the risk appetite and willingness to assess, value and purchase the risk that banks today are unwilling to own. As a consequence, niche markets such as the second-lien debt (ie unsecured and subordinated debt) have developed due to the growth of the global hedge fund industry. ${ }^{29}$

\section{Contribution to Financial Integration}

Hedge funds seek investment opportunities (ie in equity, debt and hybrids) by measuring the value and relationships of markets around the world. As a consequence, hedge funds contribute to the overall financial integration of global markets. Examples include hedge funds engaged in capital structure arbitrage, which determine the relative pricings of corporate debt, equity, hybrid and derivative instruments. It is clear that hedge fund activity contributes to the overall integration of financial markets across the investment universe.

\section{Portfolio Diversification Benefits}

Research has demonstrated that the inclusion of hedge funds in a traditional investment portfolio provides portfolio diversification benefits to investors.

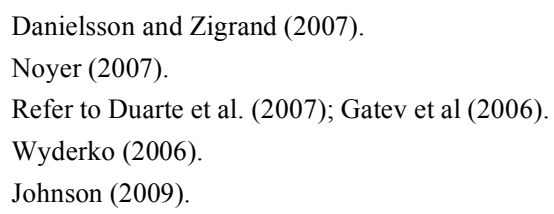

Danielsson and Zigrand (2007).

Noyer (2007).

Refer to Duarte et al. (2007); Gatev et al (2006).

Wyderko (2006).

Johnson (2009). 
Studies have revealed that the drivers of some hedge fund returns are materially different from those of other asset classes. As a result, correlation structures of some hedge funds are fundamentally different to traditional investments, such as world equities and bonds. ${ }^{30}$ Hedge funds are shown to contribute to portfolio construction via the Markowitz efficient frontier process. $^{31}$

\section{Rationale for Hedge Fund Regulatory Reform}

In the pre-GFC period, two prevailing views were adopted for the regulatory treatment of hedge funds. The first philosophy was the market-based approach to hedge fund regulation proposed by the US Federal Reserve. ${ }^{32}$ This type of regulation relies on investors and creditors to provide a powerful market mechanism for controlling risk-taking. The recent events of the GFC have tainted the market discipline approach, as many commentators incorrectly place full blame for the current crisis on the failure of the marketbased approach within the global banking sector. ${ }^{33}$ This disproportionate blame on the failure of market forces has taken hold, with politicians and the media not understanding the full impact of government-induced regulatory distortions that have also contributed to the GFC. Government induced distortions that built the GFC include the risk arbitrage caused by the Basel I and II Accords, which led to the growth of the CDO and CDS markets and the purchase of these securities by banks; the bias of the tax systems in many developed countries, which encourage debt financing that contributes to the vulnerability of the private sector to market shocks; the extended low interest rate monetary policy of the US Federal Reserve after 9/11; and the contribution of government-sponsored enterprises such as Fannie Mae and Freddie Mac, which own or guarantee nearly half of the $\$ 12$ trillion US mortgage market where the sub-prime crisis unfolded..$^{34}$

The second philosophy to hedge fund regulation is the direct government regulation approach adopted by the European Central Bank (ECB) and Bundesbank. ${ }^{35}$ While direct regulation may seem to reduce

Bacmann et al (2008).

Swensen (2000).

Bernanke (2007).

33 The speech by Australian Prime Minister Kevin Rudd (2009) at the 64th Session of the United Nations General Assembly on 23 September 2009 blames greed and unregulated markets for the GFC: 'But there remains much to be done to prevent the unrestrained greed of unregulated financial markets that has wrought such economic carnage across the world these last twelve months from sowing the seeds of future financial crises.' Again, these views communicate the disproportionate blame on the symptoms of the GFC (such as the regulation of bank executive pay) rather than directly addressing the cause, which includes excess leverage in the global economy.

34 Refer to Gramlich (2007). Fannie Mae and Freddie Mac were established by the US government to encourage US home ownership as part of federal US government policy of various administrations.

35 Ferguson (1999).
} 
financial instability, it is well recognised that tighter government policy may introduce unintended distortions in the hedge fund industry. A possible consequence of regulation may be further moral hazard whereby investors do not engage in the proper due diligence of hedge funds as they believe that regulation makes these alternative investments less risky than they really are. Second, government regulation is known to curtail innovation, efficiency and flexibility in markets.

While the relatively unregulated hedge fund environment has been successful in the past, questions are emerging in the post-GFC world about whether this framework is viable going forward. The rationale for hedge fund regulatory reform is based on the philosophy of constructing legislation to provide more efficient market forces rather than to stifle the market. The following arguments are put forward to support tighter hedge fund regulatory reform.

\section{Reduction of Systemic Risk}

The central argument for hedge fund regulatory reform is to minimise the probability of systemic risk within the global financial system. Policymakers tend to be concerned that hedge fund losses and failures may lead to financial contagion among other financial institutions, thereby causing a catastrophic failure of the entire system similar to the collapse of Lehman Brothers in September 2008. Advocates of hedge fund regulatory reform always point to the LTCM crisis of 1998 to lend support to tighter supervisory oversight; however, it is important to be reminded of the actual events that unfolded.

The spectacular fall from grace of LTCM was due to a unique set of circumstances of a very large, highly leveraged investment fund that expected the spreads between developed and developing sovereign bonds to narrow. The events of the 1997 Asian currency crisis and the Russian government bond default in August 1998 resulted in LTCM losses of US $\$ 4.4$ billion. The notification of these losses by LTCM to the US Federal Reserve led to the central bank's intervention because of its concern about potential systemic risk due to the fragility of global financial markets following the Russian government bond default a few days earlier. In the midst of the Fed Reserve coordinated private sector bailout, a consortium of banks led by Berkshire Hathaway's Warren Buffet, Goldman Sachs and American Insurance Group (AIG) Ltd offered US\$4 billion to purchase LTCM and its positions, and to continue the operations of the business. The LTCM partners declined the bid from the Warren Buffett-led consortium and instead accepted the Federal Reserve-orchestrated rescue plan financed by all Wall Street investment banks. ${ }^{36}$ In the aftermath of the crisis, the President's Working Group of Financial Markets reported that LTCM's credit exposure to the entire banking system equated to no more than 1 per 
cent of total bank credit exposures. ${ }^{37}$ Put simply, the collapse of LTCM would have resulted in a smaller impact on banks than originally estimated.

The reality is that very few companies are the size of LTCM, as the hedge fund industry comprises many small entities. The work of Getmansky reveals that the average hedge fund controls no more than US\$82 million of funds under management. ${ }^{38}$ Furthermore, empirical studies have shown that hedge fund attrition or failure rates (ie hedge fund deaths) are estimated at over 10 per cent per annum. ${ }^{39}$ It is clear that hedge fund entrepreneurs are exposed to competitive market forces that lead many to fail and exit the industry. While this industry records high levels of hedge fund failures, this competitive market behaviour has not resulted in increases in systemic risk. ${ }^{40}$ In fact, these hedge fund characteristics provide the potential solutions to minimise global systemic risk in other financial institutions. This is in stark contrast to the current argument that many highly regulated banks are 'too big to fail' ${ }^{41}$ Market forces function efficiently as long as there are many buyers and sellers of any good or service with no single entity exhibiting market power. In the case of the hedge fund industry, many hedge funds fail; however, there is no impact on systemic risk. This is the result of many small hedge funds in direct competition with each other in the alternative asset-management industry. On the contrary, when the hedge fund industry or a single fund is large enough to influence market power, then potential systemic risk arises.

As an entire industry, Table 1 compares the relative small size of the hedge fund industry with other sectors in financial markets. We can observe from Table 1 that the global hedge fund industry is a fraction in size in comparison to other sectors in the finance industry. When one adjusts the statistics in Table 1 to account for leverage, it becomes clearer that the global banking system is the primary source of systemic risk and hedge funds still remain a negligible part of the global financial system. ${ }^{42}$

\footnotetext{
37 Refer to President's Working Group on Financial Markets (1999).

38 Getmansky (2004).

39 Malkiel and Saha (2005).

$40 \quad$ Cole et al (2007).

41 Refer to Stern and Feldman (2004) and Mishkin (2006) for an overview of the 'too big to fail' debate within banking regulation.

42 King and Maier (2009) do not include the effect of leverage in their statistics. Other studies, including McGuire and Tsatsaronis (2008), estimate hedge fund leverage at between one and 10 times of assets under management, while Schneeweis et al (2005) estimate mean hedge fund leverage of between one and three times assets under management. According to Hildebrand (2008), the leverage ratio of the US banking sector operated with a capital adequacy ratio of 5 per cent (ie an implied leverage ratio was approx 20 times assets-to-equity) during the GFC. FSA (2009) reports European banks with an assets-to-equity (leverage) ratio at approximately 13 to 55 times. As a comparison, FSA (2009) employs BIS estimates of global hedge fund leverage at two to three times FUM. It is clear that the global banking system operates at much higher levels of leverage than the global hedge fund industry.
} 
Table 1: Relative size of hedge funds (US\$ trillions) ${ }^{43}$

\begin{tabular}{lllllll}
\hline Year & $\begin{array}{l}\text { Hedge } \\
\text { funds }^{\mathbf{a}}\end{array}$ & $\begin{array}{l}\text { Pension } \\
\text { funds }^{\mathbf{a}}\end{array}$ & $\begin{array}{l}\text { Mutual } \\
\text { funds }^{\mathbf{a}}\end{array}$ & $\begin{array}{l}\text { Insurance } \\
\text { companies }^{\mathbf{a}}\end{array}$ & $\begin{array}{l}\text { Global } \\
\text { assets } \\
\text { of largest } \\
\mathbf{1 0 0 0} \\
\text { banks }\end{array}$ & $\begin{array}{l}\text { Hedge } \\
\text { Funds } \\
\text { as \% } \\
\text { of } \\
\text { total }^{\mathbf{b}}\end{array}$ \\
\hline 1998 & 0.22 & 13.57 & 9.40 & 10.40 & 33.2 & 0.3 \\
1999 & 0.32 & 17.26 & 11.40 & 11.50 & 35.5 & 0.4 \\
2000 & 0.41 & 16.07 & 11.87 & 10.10 & 36.7 & 0.5 \\
2001 & 0.56 & 15.52 & 11.65 & 11.50 & 37.9 & 0.7 \\
2002 & 0.59 & 14.63 & 11.32 & 10.40 & 39.6 & 0.8 \\
2003 & 0.80 & 18.34 & 14.05 & 13.90 & 43.9 & 0.9 \\
2004 & 1.00 & 20.77 & 16.16 & 15.00 & 52.4 & 0.9 \\
2005 & 1.40 & 22.80 & 17.77 & 16.70 & 60.5 & 1.2 \\
2006 & 1.75 & 25.97 & 21.82 & 17.39 & 63.8 & 1.3 \\
$2007^{\mathbf{c}}$ & 2.25 & 28.57 & 26.20 & 19.13 & 74.2 & 1.5 \\
\hline
\end{tabular}

${ }^{\mathrm{a}}$ Global funds under management, estimated at year-end 2007.

${ }^{\mathrm{b}}$ This figure does not take into account the use of leverage.

${ }^{\mathrm{c}}$ Pension fund and insurance assets under management are estimates based on $10 \%$ growth vs 2006.

Despite the statistics in Table 1, Institutional Investment Magazine in 2007 estimated that the Top 100 hedge funds managed 75 per cent of total industry funds. Table 2 reports the year-end 2007 statistics of the largest 10 hedge funds in the world based on publicly available information. ${ }^{44}$ Table 2 suggests that the potential source of significant systemic risk does not lie within the overall global hedge fund industry, but rather exists in the topranked hedge funds due to the size of funds under management and counterparty exposures. However, Table 2 shows that the total FUM of the largest 10 hedge funds is US\$325.7 billion, still insignificant in comparison to the size of other sectors in the finance industry reported in Table 1.

\footnotetext{
43 King and Maier (2009), p 285; data sources: International Financial Services London; Investment Company Institute.

44 The source of this information includes the SEC ADV Form, Company Information and SEC Investment Adviser Disclosure Forms.
} 
Table 2: Largest ten hedge fund managers as at 31 December $2007^{45}$

\begin{tabular}{lll}
\hline Rank & Hedge fund & $\begin{array}{l}\text { Assets under } \\
\text { management (US } \\
\text { billions) }\end{array}$ \\
\hline 1 & JP Morgan Asset Management & 44.7 \\
2 & Bridgewater Associates & 36.0 \\
3 & Farallon Capital Management & 36.0 \\
4 & Renaissance Technologies Corporation & 33.3 \\
5 & Och-Ziff Capital Management & 33.2 \\
6 & D.E. Shaw Group & 33.0 \\
7 & Goldman Sachs Asset Management & 32.5 \\
8 & Paulson \& Co & 29.0 \\
9 & Highbridge Capital Management & 28.0 \\
10 & Barclays Global Investors & 20.0 \\
\hline & Total & 325.7 \\
\hline
\end{tabular}

\section{Increased Investor Protection}

In the past, hedge funds were the domain of high net worth individuals who did not require the protection of financial market regulation. Today, the evolution of financial markets has made hedge fund investment products readily available to 'retail' or 'mum and dad' investors. Financial services regulation serves to protect these less sophisticated investors from unexpected losses due to their lack of expertise in alternative assets such as hedge funds. Furthermore, the emergence of Australian superannuation funds and international pension funds allocating long-term investor capital to hedge funds has lent support for tighter regulation in this sector of the financial services industry. On the basis of investor protection, some argue that hedge fund regulatory reform must include closer prudential supervision and oversight.

The recent failures of Australian hedge funds lend support to the case for increased investor protection. The demise of the Australian hedge funds, Basis Capital Yield Fund and the Absolute Capital Yield Strategies Fund due to losses suffered in collateralised debt obligations (CDOs) has caused extensive wealth destruction for many retail investors. In the United States, the recent collapse of Amaranth in 2006 and the Bear Stearns High Grade Structured Credit Enhanced Leverage Master Fund Ltd in 2007 have lent support to the calls for tighter hedge fund regulation. ${ }^{46}$

45 Institutional Investor Magazine, ranked as at end of 2007; Pensions and Investments Magazine, ranked as at 31 December 2007.

46 The current net asset value of the Absolute Capital Yield Strategies Fund can be located at www.ysf.com.au, where its reported 12-month performance to 31 July 2009 is -59.65 per cent and its annualised performance since inception is -11.77 per cent. In the case of the Basis Yield Alpha Fund, its Master Fund, which is a legal entity domiciled in the Caymans Islands, was placed into provisional liquidation on 30 August 2007 and little or no publicly available information has been forthcoming. Refer to Ray (2006) for an 


\section{Regulate Financial Innovation}

In global financial markets, the hedge fund industry is recognised as one of the bastions of financial innovation. Many investment products and services developed by the hedge fund industry include short selling, market (or beta) neutral strategies, commodities and exotic-based investments, among others. ${ }^{47}$ While these financial innovations enrich the choice of alternative investments, they also draw support for tighter hedge fund regulation. The case for tighter oversight also relates to the financial innovation that led to the recent development and trading of collateralised debt obligations (CDOs) and credit default swaps (CDSs), which contributed to catastrophic losses in the US banking, insurance and mortgage sectors.

\section{Proposed Hedge Fund Regulatory Reform}

In the post-GFC world, various government agencies are developing proposals for tighter hedge fund regulation. As we enter this new era of financial regulatory oversight, we can view and assess hedge fund regulation within the three domains of: (1) systemic risk reduction; (2) moderating financial innovation; and (3) investor/consumer protection.

On 15 January 2009, the G30 (2009) Financial Reform Report recommended oversight of hedge funds or private pools of capital. The G30 acknowledged the success of the largely unregulated hedge fund industry; however, questions were raised about its viability going forward given the systemic events of the GFC. The G30 proposed a regime of limited and flexible hedge fund regulation through greater hedge fund transparency to the relevant regulator in terms of size, leverage, risk styles and other variables that may be regarded as important. The G30 rationale for regulatory hedge fund oversight is its concern that a single large fund with complex market exposures may eventually become a future source of significant systemic risk. This shift towards increasing regulatory oversight of hedge funds was also confirmed by the $\mathrm{G} 20 .^{48}$

The broad-based recommendations of the G30 (2009) were translated into concrete outcomes with the release of the IOSCO six principles of hedge funds in June 2009.49 The IOSCO recommendations include: (1) mandatory registration; (2) hedge funds to be subject to new disclosure requirements; (3) mandatory registration/regulation/supervision of prime

introduction to collateralised debt obligations (CDOs), while Longstaff and Rajan (2008) provide a more rigorous treatment of these securities.

47 Refer to Bris et al (2008); Dechow et al (2001); Jones and Lamont (22); Ofek and Richardson (2003) for empirical evidence that supports the critical role of short sellers as providers of liquidity, price discovery and efficiency. In the post-GFC literature, studies by Curtis and Fargher (2008), Clifton and Snape (2008), Boehmer, Jones and Zhang (2008) and Hamson et al (2008) continue to advocate short sellers as important participants in financial markets.

$48 \quad$ G20 (2009).

49 $\operatorname{IOSCO}(2009 b)$. 
brokers and banks who provide funding (ie leverage) to hedge funds; (4) hedge funds to provide relevant information on systemic risk to their relevant regulator; (5) regulators to encourage the development of better industry practices; and (6) the development of global regulatory cooperation.

The recommendations from the G30 and IOSCO go some way towards minimising the potential of significant systemic risk from hedge funds. Despite the best efforts of government agencies, the above recommendations introduce some interesting consequences. First, the proposed framework for improved disclosure and transparency is an elementary start for policymakers to better understand the behaviour of the hedge fund industry. Second, the proposed regulations from IOSCO provide disclosure flexibility for small hedge funds that pose no systemic risk. This opt-out clause for smaller funds limits the distortion effects of tighter regulation. This suggests that the impact of new hedge fund regulation will be borne by large hedge funds, which pose potential significant systemic risk. Third, the proposed regulation does not effectively address the issue of excessive leverage, which has been found to be one of the main contributors to the GFC across many financial market participants. We proceed to examine the impacts of disclosure, the impact of large hedge funds and the unresolved issue of excessive leverage.

\section{Regulatory Reform, Excess Leverage and Disclosure}

The key issues in the post-GFC world for the global hedge fund industry are (1) the development of a framework to constrain the use of excessive leverage; and (2) the requirement to increase hedge fund disclosure and transparency to regulatory authorities. As with all regulation, there exists the possibility of market distortions whereby various benefits or costs may accrue to individual hedge funds, investors and regulatory agencies as a consequence of this reform.

First, it is clear that one of the primary causes of the GFC was excessive leverage in the banking system and across many financial market sectors..$^{50}$ The recent house price declines in the United States and Europe reflect the risks associated with high levels of household debt. ${ }^{51}$ Furthermore, we have seen the introduction of Australian government intervention to moderate consumer credit (ie credit cards and margin lending) practices. ${ }^{52}$ The lessons of the 1928-29 US stockmarket boom and crash, the Japan bubble and bust of the 1980s-90s and the most recent GFC are a function of excess leverage in the financial system..$^{53}$ The Turner Review shows that these high levels of leverage were reflected in some of the world's largest investment banks,

\footnotetext{
50 D'Hulster (2009); FSA (2009); FSB (2009); Hildebrand (2008); Issing (2009); de Larosiere (2009); Marks (2009).

51 Brunnermeier (2009); Kiff and Mills (2007); Klyuev (2008); Shiller (2007).

52 ASIC (2009) has introduced new regulation in relation to moderating consumer credit (ie credit cards and margin lending) for both consumption and investment practices.

53 Ferguson (2008).
} 
which operated with leverage (ie the ratio of assets to equity) of between 12 and 97 times during the 2000-08 period. The upper end of this statistical range is staggering. The same report also shows that major UK commercial banks operated with leverage levels between 15 and 60 times over the same period. Again, the dizzying heights of this leverage is a disturbing statistic given that commercial (ie deposit-taking) banks are the 'pillars' and the most highly regulated entities of the modern financial system. The aftermath of the GFC has ignited the call to implement new bank regulation to moderate the aggregate level of bank leverage over and above the current Basle riskadjusted capital framework, which failed to moderate the impact of excessive bank leverage. ${ }^{54}$

In terms of hedge funds, little is known about their use of leverage due to the voluntary disclosure regime within the industry. There are specific hedge funds strategies (such as convertible-arbitrage, market-neutral and fixed-income arbitrage) that seek arbitrage opportunities by capturing small profitable inefficiencies in financial markets. To magnify these small arbitrage profits, leverage is employed to deliver more acceptable returns to investors. Research has shown that the hedge fund industry reports a mean leverage ratio of 2.7 to 5.3 times with maximum leverage levels of up to 17.3 times. $^{55}$ Other research reports median leverage statistics of one to three times in various hedge fund investment strategies. ${ }^{56}$ In the same study, Convertible Arbitrage funds reported the highest median leverage of three times, while Equity Market Neutral funds recorded the second highest median leverage at two times. It is clear that hedge fund leverage operates at a fraction in comparison to the leverage employed in the global banking sector.

From a regulatory perspective, it is becoming clear that concerns regarding hedge fund leverage are perhaps less problematic now than initially thought. This is reflected in the Turner Review published at the height of GFC, which found that hedge funds employ relatively low levels of leverage in comparison to the banking sector. In an effort to collect hedge fund information, a survey by the Financial Services Authority in the United Kingdom found that these pools of capital operate with a leverage at between two and 10 times, which is relatively low when compared to the banking sector. ${ }^{57}$ An interesting observation from the survey shows that the Fixed Income Arbitrage funds report the highest levels of leverage within the hedge fund industry.

The regulatory reform proposed by IOSCO also recommends the mandatory registration/regulation/supervision of prime brokers and banks that supply funding (ie credit) to hedge funds. This shift towards the monitoring of hedge fund leverage is prudent and consistent with the management of potential systemic risk in the future. The fly in this ointment

Hildebrand (2008).

Gupta and Liang (2005).

Schneeweis et al (2005).

FSA (2010). 
occurs when the monitoring of hedge fund leverage shifts towards the rationing of hedge fund leverage, as it would cause two unintended consequences. First, the constraint on leverage will severely impact on arbitrage-type investment strategies, such as convertible arbitrage, fixed income arbitrage and equity market neutral. Going forward, the implications for these managers are that the ex-ante returns delivered will not be as attractive as historical rates of return due to the dampening effect caused by lower levels of leverage. This has a direct impact on institutional and retail hedge fund investors. Second, the rationing of leverage to arbitrage-based hedge funds will result in lower levels of market liquidity, less efficient price discovery and more price distortions as less capital can be deployed in markets to capture price inefficiencies. Effectively, markets may become less efficient in a leverage-constrained world as this type of regulation will limit the arbitrage practices of some hedge funds.

The monitoring of hedge fund leverage as per the IOSCO recommendations will be executed through the monitoring of prime brokers (ie the providers of hedge fund credit), which are effectively the subsidiary entities of the banking sector. Prime brokers source their leverage through their banking parent. While it is prudent to measure and monitor the level of hedge fund leverage, the problematic issue of excessive leverage remains in the realms of banking regulation reform rather than with hedge funds. We can conclude that the events of the GFC and the empirical evidence to date suggest that the most efficient approach to moderate leverage is through regulatory reform of the banking sector.

Second, the IOSCO recommendation to increase hedge fund disclosure and transparency requirements is an important initiative to gather better information to assess the systemic risks within the hedge fund industry. However, this new recommendation for increased disclosure and transparency raises a number of benefits and concerns for regulators and hedge funds. First, increased disclosure and transparency to regulatory agencies are vital for the collection of elementary information on hedge fund investment exposures and risk statistics. From a regulatory perspective, this recommendation is applauded as little progress on the hedge fund reform debate can proceed without the empirical evidence to support regulation, or otherwise. The aggregate information of market positions and risks of the hedge fund industry will improve the regulatory understanding in identifying and measuring the potential sources of systemic risk from the hedge fund industry.

However, it will come as no surprise that hedge funds will strongly resist this increased disclosure reform. Regulators must be cognisant of the fact that the most important intangible asset of a hedge fund manager's business is the nature of their security selection and how these securities and financial instruments are constructed within their investment portfolio. This new reporting regime may disclose the central source of information that determines how a hedge fund delivers excess returns to its investors. In other words, a great deal of market intelligence and intellectual property would be transferred from each individual hedge fund to their respective regulator 
under this new disclosure regime. Historically, the value of financial innovation and entrepreneurship in a hedge fund business has been strongly protected through its opaque transparency and lack of disclosure. The transfer of market position information (or the lack of) is a source of conflict between successful hedge fund businesses, which wish to protect their competitive advantage and the needs of regulatory agencies to measure and monitor potential systemic risk.

To resolve this conflict, the new regime of higher disclosure and transparency must be constructed in an environment that satisfies both parties. One possible solution is the development of a 'disclosure clearing house', whereby the information provided by each individual hedge fund is protected in two ways. First, the regulator utilises the aggregate information only from this 'clearing house' in order to measure and monitor systemic risk. The regulator can only access the individual market positions with the consent of the individual hedge fund. At all times, the regulator may never publicly report the position of a single entity or hedge fund. In the event of a hedge fund failure, the regulator would receive immediate private access to the fund's market positions but they will never be disclosed to the public.

The information from the individual hedge fund may be inputted via a private identification number, which remains anonymous or 'unidentified'. This means that the regulator does not know the owner of the positions until specific systemic risk measures have been breached and the regulator is obliged to instigate action to overcome systemic risk. This solution will allow individual hedge funds to disclose their individual positions without threatening the value of their underlying business. The economics of information asymmetry and efficient market hypothesis tell us that all financial market participants would exploit individual hedge fund information in the event that these hedge fund market positions are disclosed to the general public. ${ }^{58}$ Under this extreme scenario, financial market participants would analyse their competitors' investment philosophies and strategies until the extraordinary profits derived from these investment strategies are arbitraged or traded away. We can conclude that the IOSCO recommendations of higher disclosure requirements must be developed and executed with a great deal of sensitivity in order to gain support from the hedge fund industry so that financial innovation and entrepreneurship can continue to prosper within this new regulatory environment.

While regulatory reform of the hedge fund industry will assist regulatory agencies in the monitoring and measurement of systemic risk, it does not treat the primary cause of the problem, which is excessive leverage. Rather than allocating scarce resources to hedge fund regulation, we advocate the implementation of a broader framework to moderate excessive leverage across all sectors in financial markets. It is too narrow to target one or two sectors within financial markets (ie hedge funds), as excessive leverage would be simply redeployed in other parts of the economy. The

Refer to Fama (1970) on the Efficient Market Hypothesis and Stiglitz (2000) for a review of information economics. 
narrow targeting of hedge fund regulation will only cause market distortions in other parts of the global financial system. The reduction in the likelihood of systemic risk in the future can be addressed by imposing clearer limits on leverage in the global financial system via the banking sector, which is the primary source of credit.

\section{Concluding Comments}

The premise that tighter hedge fund regulation is the panacea for financial market reform post-GFC requires delicate and careful consideration. Financial history is littered with government policy errors that have caused financial crises. The Federal Reserve tightening of the money supply in 1928-29 has been regarded as the primary cause of the 1929 stockmarket crash and subsequent Great Depression. ${ }^{59}$ The US Federal Reserve is argued to have kept interest rates too low after the events of 9/11, and governmentsponsored Fannie Mae and Freddie Mac were the primary lenders of US mortgages, encouraging US home ownership to marginal borrowers; these were the sub-prime lending catalysts of the current GFC. ${ }^{60}$ It is clear that government intervention and policy can distort markets to the point of causing financial crises themselves. Regulatory reform in the future must ensure that hedge funds are not penalised at the distorted benefits of others.

The concern towards more hedge fund regulation in a post-GFC world is supported by Jan Redfern, who argues that further financial market regulation is pointless unless government regulators adopt an evidence-based approach to evaluate the impact of current and proposed regulatory frameworks. ${ }^{61}$ Friedman offers another perspective by blaming the source of the GFC on the complexity of current regulation, which has resulted in a hybrid capitalism that makes it impossible to predict and remedy economic problems as they emerge. ${ }^{62}$ Ferguson insists that bad regulation often causes crises more than deregulation. ${ }^{63}$ It is clear that the disproportionate advocacy for tighter financial regulation at this moment in time must be tempered and moderated.

This battle of ideas between free markets versus government intervention will be debated for years to come. At this stage, the critics of free markets hold the higher ground. The advocates for hedge fund regulation must acknowledge that excessive leverage from the highly regulated banking sector caused the GFC whilst the relatively unregulated industry sustained little or minor losses only. The lesson from the GFC is that regulation does not translate into financial stability as the highly regulated banking sector has demonstrated in 2008. Rather than stifling financial innovation and entrepreneurship out of the hedge fund industry

Friedman and Schwartz (1963); Bernanke (2002).

Taylor (2009).

Redfern (2009).

Friedman (2009).

Ferguson (2009). 
with regulation, perhaps it is more prudent to deal with the problem itself by developing new policy to limit excess leverage by all participants in society, including individuals, corporations and governments.

\section{References}

Vikas Agarwal and Narayan Y Naik (2004) 'Risks and Portfolio Decisions Involving Hedge Funds' 17 Review of Financial Studies 63.

Vikas Agarwal, Naveen D Daniel and Narayan Y Naik (2009) 'Role of Managerial Incentives and Discretion in Hedge Fund Performance' 64 Journal of Finance 2221.

Luis A Aguilar (2009) 'Hedge Fund Regulation on the Horizon - Don't Shoot the Messenger', Speech by SEC Commissioner, Hedgeworld Fund Services Conference, 18 June, New York.

Australian Securities and Investments Commission (ASIC) (2009) 'ASIC Consults on Licensing Requirements For Credit Licenses’, Media Release No. 09-124MR, 15 July.

Australian Prudential Regulation Authority (APRA) (2003) 'APRA Alerts Super Industry to the Drawbacks of Hedge Funds', Media Release No. 03.25, 5 March.

Jean-Francois Bacmann, Pierre Jeanneret and Stefan Scholtz (2008) 'What Correlation Does Not Tell You About Hedge Funds: A Factor Approach to Hedge Fund Correlations' 14 Journal of Derivatives and Hedge Funds 90.

Ben S Bernanke (2002) 'On Milton Friedman's Ninetieth Birthday', Remarks by Federal Reserve Governor Ben S Bernanke, Conference to Honor Milton Friedman, University of Chicago, 8 November.

Ben S Bernanke (2007) 'Financial Regulation and the Invisible Hand', New York University Law School, 11 April.

Ekkehart Boehmer, Charles M. Jones and Xiaoyan Zhang (2009) 'Shackling Short Sellers: The 2008 Short Selling Ban', Working Paper, Johnson School Research Paper Series No. 34-09 Unpublished Paper, 28 July.

Richard Bookstaber (2009) Hearing on 'Regulating Hedge Funds and Other Private Investments Pools', Submitted to the Senate of the United States, Committee on Banking, Housing, and Urban Affairs Subcommittee on Securities, Insurance and Investment, 15 July.

Arturo Bris, William N Goetzmann and Ning Zhu (2008) 'Efficiency and the Bear: Short Sales and Markets Around the World' 62 Journal of Finance 1029.

Stephen J Brown and William N Goetzmann (2003) 'Hedge Funds with Style' 29 Journal of Portfolio Management 101.

Stephen Brown, William Goetzmann, Bing Liang and Christopher Schwarz (2008) 'Mandatory Disclosure and Operational Risk: Evidence from Hedge Fund Registration' 63 Journal of Finance 2785.

Markus K Brunnermeier (2009) 'Deciphering the Liquidity and Credit Crunch 2007-2008' 23 Journal of Economic Perspectives 77.

Jess H Chua and Richard S Woodward (1983) 'JM Keynes's Investment Performance: A Note' 38 Journal of Finance 232.

Matthew Clifton and Mark Snape (2008) 'The Effect of Short-Selling Restrictions on Liquidity: Evidence from the London Stock Exchange', Working Paper, University of Technology Sydney and University of Sydney, 19 December.

Roger T Cole, Greg Feldberg and David Lynch (2007) 'Hedge Funds, Credit Risk Transfer and Financial Stability' 10 Financial Stability Review 7. 
Philipp Cottier (1997) Hedge Funds and Managed Futures: Performance, Risks, Strategies, and Use in Investment Portfolios, Verlag Paul Haupt.

Asher Curtis and Neil L Fargher (2008) 'Does Short-Selling Amplify Price Declines or Align Stocks with their Fundamental Values?' Working Paper, Social Science Research Network (SSRN), 19 December.

Jon Danielsson and Jean-Pierre Zigrand (2007) 'Regulating Hedge Funds' 10 Banque de France, Financial Stability Review 29 (Special Issue on Hedge Funds, April).

Gordon de Brouwer (2001) Hedge Funds in Emerging Markets, Cambridge University Press.

Patricia M Dechow, Amy P Hutton, Lisa Meulbroek and Richard G Sloan (2001) 'Short-Sellers,

Fundamental Analysis, and Stock Returns' 61 Journal of Financial Economics 77.

Jacques de Larosiere (2009) The High-Level Group on Financial Supervision of the EU, Report, $25^{t}$ February, EU.

Jefferson Duarte, Francis A Longstaff and Fan Yu (2007) 'Risk and Return in Fixed Income Arbitrage: Nickels in Front of a Steamroller' 20 Review of Financial Studies 769.

Katia D'Hulster (2009) 'The Leverage Ratio: A New Binding Limit on Banks', Crisis Response: Public Policy for the Private Sector, World Bank Group, Note Number 11, December.

Franklin R Edwards (1999) 'Hedge Funds and the Collapse of Long Term Capital Management' 13 Journal of Economic Perspectives 189.

Franklin R Edwards and Stav Gaon (2003) 'Hedge Funds: What Do We Know?' 15 Journal of Applied Corporate Finance 58.

Eugene F Fama (1970) 'Efficient Capital Markets: A Review of Theory and Empirical Work' 25 Journal of Finance 383.

Niall Ferguson (2008) The Ascent of Money, Allen Lane, London.

Niall Ferguson (2009) 'Diminished Returns', New York Times, 17 May.

Roger W Ferguson Jr (1999) 'Alternative Approaches to Financial Supervision and Regulation' 16 Journal of Financial Services Research 297.

Financial Services Authority (FSA) (2009) The Turner Review: A Regulatory Response to the Global Banking Crisis, FSA.

Financial Services Authority (FSA) (2010) 'Assessing Possible Sources of Systemic Risk from Hedge Funds', FSA.

Financial Stability Board (FSB) (2009) Report of the Financial Stability Forum on Addressing Procyclicality in the Financial System, FSB.

Jeffrey Friedman (2009) 'A Crisis of Politics, Not Economics: Complexity, Ignorance, and Policy Failure’ 21 Critical Review 127.

Milton Friedman and Anna J Schwartz (1963) A Monetary History of the United States, Princeton University Press.

William Fung and David Hsieh (1997) 'Empirical Characteristics of Dynamic Trading Strategies: The Case of Hedge Funds' 10 Review of Finance Studies 275.

William Fung and David Hsieh (1999) 'A Primer on Hedge Funds' 6 Journal of Empirical Finance 309.

Evan Gatev, William N Goetzmann and K Geert Rouwenhorst (2006) 'Pairs Trading: Performance of a Relative Value Arbitrage Rule' 19 Review of Financial Studies 797.

Mila Getmansky (2004) 'The Life Cycle of Hedge Funds: Fund Flows, Size and Performance', Working Paper, MIT Sloan School of Management, 16 January.

Edward M Gramlich (2007) Subprime Mortgages: America's Latest Boom and Bust, The Urban Institute Press. 
Group of Thirty (G30) (2009a) 'Communique', Meeting of Finance Ministers and Central Bank Governors, G30, 14 March.

Group of Thirty (G30) (2009b) Financial Reform: A Framework for Financial Stability, G30, 15 January.

Anurag Gupta and Bing Liang (2005) 'Do Hedge Funds Have Enough Capital? A Value-at-Risk Approach' 77 Journal of Financial Economics 219.

Don Hamson, Manoj Wanzare, Gavin Smith and Peter Gardner (2008) 'Has the Short Selling Ban Reduced Liquidity in the Australian Stock Market?' 4 JASSA The Finsia Journal of Applied Finance 14.

Richard J Herring (2004) 'The Subordinated Debt Alternative to Basel II' 1 Journal of Financial Stability 137.

Philipp Hildebrand (2008) 'Is Basel II Enough? The Benefits of a Leverage Ratio' ViceChairman of the Governing Board of the Swiss National Bank, Financial Markets Group Lecture, London School of Economics, 15 December.

International Monetary Fund (IMF), 1998, Hedge Funds and Financial Market Dynamics, Occasional Paper 166, IMF.

International Organization of Securities Commissions (IOSCO) (2009a) 'IOSCO Publishes Principles for Hedge Funds Registration’, Media Release, IOSCO Technical Committee, 22 June.

International Organization of Securities Commissions (IOSCO) (2009b) 'Hedge Funds Oversight Final Report', Technical Committee of the International Organization of Securities Commissions, June.

Otmar Issing (2009) 'Asset Prices and Monetary' 29 Cato Journal 45.

David L Johnson (2009) 'The Changing Shape of Distressed Financing: Trends Driving the Evolution of a Market' 12 Journal of Private Equity 73.

Charles M Jones and Owen A Lamont (2002) 'Short-Sale Constraints and Stock Returns' 66 Journal of Financial Economics 207.

John Kiff and Paul Mills (2007) Money for Nothing and Checks for Free: Recent Developments in US Subprime Mortgage Markets, International Monetary Fund, IMF Working Paper $\mathrm{WP} / 07 / 188$.

Michael R King and Philipp Maier (2009) 'Hedge Funds and Financial Stability: Regulating Prime Brokers Will Mitigate Systemic Risks' 5 Journal of Financial Stability 283.

Vladimir Klyuev (2008) What Goes Up Must Come Down? House Price Dynamics in the United States, International Monetary Fund, IMF Working Paper WP/08/187.

Francois-Serge Lhabitant (2004) Hedge Funds: Quantitative Insights, John Wiley \& Sons, West Sussex.

Francis A Longstaff and Arvind Rajan (2008) 'An Empirical Analysis of the Pricing of Collateralized Debt Obligations' 63 Journal of Finance 529.

Carol Loomis (1966) 'The Jones Nobody Keeps Up With' Forbes Magazine, April, p 37.

Roger Lowenstein (2001) When Genius Failed, Fourth Estate.

Burton G Malkiel and Atanu Saha (2005) 'Hedge Funds: Risk and Return' 61 Financial Analysts Journal 80.

Robert E Marks (2009) 'Anatomy of a Credit Crisis' 34 Australian Journal of Management 1.

Patrick McGuire and Kostas Tsatsaronis (2008) Estimating Hedge Fund Leverage, Bank for International Settlements, Monetary and Economic Department, BIS Working Paper No. 260, September. 
Frederic S Mishkin (2006) 'How Big a Problem is Too Big to Fail? A Review of Gary Stern and Ron Feldman's Too Big to Fail: The Hazards of Bank Bailouts' 44 Journal of Economic Literature 988.

Mark Mitchell and Todd Pulvino (2001) 'Characteristics of Risk and Return in Risk Arbitrage' 56 Journal of Finance 2135.

Christian Noyer (2007) 'Hedge Funds: What are the Main Issues?' 10 Banque de France, Financial Stability Review 105 (Special Issue on Hedge Funds).

Eli Ofek and Matthew Richardson (2003) 'DotMania: The Rise and Fall of Internet Stock Prices' 58 Journal of Finance 1113.

President's Working Group on Financial Markets (1999) Hedge Funds, Leverage and the Lessons of Long Term Capital Management, US Government.

Russ Ray (2006) 'CDOs Cubed: The First Ever Triple Derivative' 12 Derivatives Use, Trading and Regulation 183.

Jan Redfern (2009) 'Good Regulation Comes from Quality Research', Australian Financial Review, 18 September, $\mathrm{p} 59$.

Reserve Bank of Australia (RBA) (2009) Financial Stability Review, Reserve Bank, Canberra, March.

Kevin Rudd (2009), Prime Minister of Australia, Address to the 64th Session of the United Nations General Assembly, New York, 23 September.

Hector Sants (2008) 'The Regulator's View of Hedge Funds and Hedge Fund Standards', Speech by Chief Executive, FSA, Hedge 2008 Conference, 22 October.

Thomas Schneeweis, George Martin, Hossein Kazemi and Vassilis Karavas (2005) 'The Impact of Leverage on Hedge Fund Risk and Return' 7 Journal of Alternative Investments 10.

Myron Scholes (2004) 'The Future of Hedge Funds' 1 Journal of Financial Transformation 8.

US Securities and Exchange Commission (SEC) (2003) Implications of the Growth of Hedge Funds, SEC Special Studies, 29 September.

Robert J Shiller (2007) 'Understanding Recent Trends in House Prices and Home Ownership', Cowles Foundation Discussion Paper No. 1630, Cowles Foundation for Research in Economics, Yale University.

Gary H Stern and Ron J. Feldman (2004) 'Too Big to Fail: The Hazards of Bank Bailouts' Brookings Institute Press.

Joseph E Stiglitz (2000) 'The Contributions of the Economics of Information to Twentieth Century Economics' 115 Quarterly Journal of Economics 1441.

David F Swensen (2000) Pioneering Portfolio Management: An Unconventional Approach to Institutional Investment, The Free Press.

John B Taylor (2009) 'Economic Policy and the Financial Crisis: An Empirical Analysis of What Went Wrong' 21 Critical Review 341.

Susan Ferris Wyderko (2009) Testimony Concerning Hedge Funds, Director, Office of Investor Education and Assistance, US Securities and Exchange Commission, The Subcommittee on Securities and Investments of the US Senate Committee on Banking, Housing and Urban Affairs, 16 May. 
Reproduced with permission of the copyright owner. Further reproduction prohibited without permission. 